Røen, U. 1962: Studies on freshwater Entomostraca in Greenland II. Meddr Grønland 170(2), 249 pp. Salomonsen, F. 1981: Fugle. In Salomonsen, F. (edit.) Grønlands fauna, 161-361. Copenhagen: Gyldendal.

Van Geel, B. 1979: Preliminary report on the history of Zygnemataceae and the use of their spores as ecological markers. Proc. 4. int. Palynol. Conf., Lucknow (1976-77) 1, 467-469.

Van Geel, B. \& Van der Hammen, T. 1978: Zygnemataceae in Quaternary Colombian sediments. Rev. Palaeobot. Palynol. 25, 377-392.

Geologisk Museum,

Oster Voldgade 5-7, DK-1350 Copenhagen $K$.

\title{
Mapping of the Isukasia sheet, southern West Greenland
}

\author{
A. A. Garde, R. P. Hall, D. J. Hughes, S. B. Jensen, A. P. Nutman \\ and $\mathrm{O}$. Stecher
}

Field work for the Isukasia map sheet north of Godthåbsfjord, started in 1981 (Allaart et $a l ., 1982$ ), was continued in 1982. A tent base camp was set up at the fjord Kangiussaq both summers.

In 1982 seventeen field teams and the glaciological station Qamanârssûp sermia were supplied from the base by the GGU cutter J. F. Johnstrup and by a Jet Ranger helicopter based in Kangiussaq. Twelve mapping geologists worked on the two map sheets Ivisârtoq and Isukasia, and five teams carried out ore geological, geochemical and geophysical investigations (see Appel, Chadwick et al., Jensen \& Secher, and Secher, this volume). The field work was carried out from June 20th to August 28th.

The Isukasia map sheet is situated north-east of the head of Fiskefjord, around the lake Taserssuaq. To the east it is bounded by the Inland Ice, from which the glacier Sarqap sermia enters Taserssuaq. Most of the area is a lake strewn, undulating plateau at elevations between 500 and $800 \mathrm{~m}$. Outcrops are generally good although there are some Quaternary boulder fields, the largest of which extends over some $25 \mathrm{~km}^{2}$ in the north-east corner of the map sheet.

The north-north-east trending Ataneq fault zone (see below), which occurs some $25 \mathrm{~km}$ east of Taserssuaq, separates an area of early Archaean rocks (including the Isua supracrustals) from rocks to its west of probable late Archaean age. The younger rocks make up the bulk of the Isukasia map sheet.

\section{Early Archaean rocks east of the Ataneq fault}

In 1982 A.P.N. mapped two areas east of the Ataneq fault: close to the map sheet boundary at $65^{\circ} \mathrm{N}$ and north of the north-eastern splay of the Ataneq fault (fig. 7). It was 
confirmed that the Tarssartôq (Ameralik?) dyke swarms (Nutman et al., in press) continue southwards at least to $65^{\circ} \mathrm{N}$ from the area studied in 1981 (Nutman, 1982), suggesting that this area is dominated by early Archaean rocks. However, just east of the Ataneq fault there is a unit up to $1500 \mathrm{~m}$ wide of nebulitic, granodioritic to tonalitic gneiss with sparse pegmatite banding that is not cut by Tarssartôq dykes. The dykes adjacent to this unit are heavily broken up by deformed aplitic to pegmatitic sheets.

Within a few kilometres north of $65^{\circ} \mathrm{N}$ and east of the Ataneq fault the dominant lithology is layered gneiss comprised of strongly deformed tonalitic and granitic components considered to be broadly equivalent to the gneisses found in the area within the arc of the Isua supracrustal belt. The gneisses intrude and are intercalated with units of supracrustal rocks, most of which are of Akilia association (McGregor \& Mason, 1977) affinities. The supracrustal rocks comprise layered, locally garnetiferous hornblende-plagioclase amphibolite, clinopyroxene- and hornblende-rich stripey green amphibolite, metaperidotitic lenses, and thin units of quartz-magnetite banded iron formation, quartz- and amphibole-laminated metasediment and laminated felsic gneisses. An exceptional unit $2.5 \mathrm{~km}$ from the Ataneq fault is lithologically similar to formation A3 of the Isua supracrustal belt (Nutman et al., in press) and contains lenses of leucoamphibolite similar to the garbenschiefer unit in the Isua supracrustal belt. Another unusual unit, which occurs $1 \mathrm{~km}$ from the fault, is comprised predominantly of layered, leucocratic amphibolite, but no diagnostic Akilia association or Isua supracrustal belt lithologies were observed.

On the north side of the north-eastern splay of the Ataneq fault, Tarssartôq dykes are preserved as highly deformed strips of biotite-bearing amphibolite. Some contain numerous plagioclase aggregates and some are still discordant to the layering in the adjacent gneisses. The dykes are extensively cut by deformed leucocratic sheets. Northwards deformation is much more extreme and the amount of leucocratic sheets increases. Strips of homogeneous amphibolite with rare streaked-out plagioclase aggregates occur, but there is no conclusive evidence that they are remains of basic dykes. There are also rare, small inclusions of quartz-rich rock and diopsidic amphibolite in the gneisses, and quartz-magnetite-banded iron formation is exposed at one locality. The presence of such supracrustal rocks and Tarssartôq dykes are evidence that the quartzo-feldspathic gneisses in the area contain an early Archaean component, which may however decrease northwards.

The early Archaean tectonic history of the area east of the Ataneq fault is described elsewhere (Nutman, 1982; Nutman et al., in press); this account will be confined to events after the intrusion of the Tarssartôq dykes. Two stages of deformation are important; an earlier event of flattening has caused a progressive reorientation of the Tarssartôq dykes to the south and east of the Isua supracrustal belt. In areas strongly affected by this event the rocks bear greater resemblance to the early Archaean rocks south of Godthåb than to the better preserved, nearby Isua supracrustal belt and adjacent gneisses.

After the flattening event a large overturned, west-vergent antiform structure was developed with a south-plunging axis and north-north-east trending axial trace. The fold extends southwards onto the Ivisârtoq map sheet (the Kangerssuaq antiform, Chadwick et $a l$., this volume).

Two phases of amphibolite facies metamorphism have affected the Tarssartôq dykes in the southern part of the area east of the Ataneq fault. In the first phase, perhaps contemporaneously with the flattening event, hornblende-garnet-plagioclase assemblages and small metamorphic or partial melt sweats formed in the dykes. The second phase, perhaps as- 
sociated with the development of the antiform, is characterised in the dykes by the paragenesis of hornblende and plagioclase, with breakdown of previously formed garnet to plagioclase-amphibole intergrowths and the deformation of the sweats formed in the first phase of metamorphism.

\section{Amphibolites and ultramafic rocks west of the Ataneq fault}

West of the Ataneq fault the oldest recognisable rocks comprise one or more complexes of amphibolite and associated ultramafic rocks. The amphibolites are typically fine grained and finely banded to massive. Locally in the western part of the area they grade into more massive two-pyroxene-bearing granulite-facies equivalents, and where they are strongly deformed biotite partially replaces hornblende, producing schistose biotite (-hornblende) plagioclase rocks. At least some of the fine-grained, banded amphibolites are of extrusive volcanic origin. Strongly lineated relict pillow structures are preserved within the large amphibolite horizon around $65^{\circ} 17^{\prime} \mathrm{N}, 51^{\circ} 15^{\prime} \mathrm{W}$ (Hall \& Hughes, 1982) and $65^{\circ} 11^{\prime} \mathrm{N}$, $51^{\circ} 23^{\prime} \mathrm{W}$. There are also medium- to coarse-grained amphibolites and leuco-amphibolites, particularly within the larger horizons, which appear to be remnants of gabbro complexes and sills. However, variations in grain size and banding can often be related in the field to the post-magmatic tectono-metamorphic history of the rocks.

Metasedimentary rocks are only rarely associated with the amphibolites, but small amounts of cordierite-bearing metasedimentary gneisses have been found by O.S. in the north-eastern part of the area. Pods, lenses and more rarely continuous bands of ultramafic rocks are commonly associated with the amphibolites, and form large horizons in the north-eastern part of the area. They are predominantly olivine-rich rocks with equigranular metamorphic textures and often with subordinate ortho- and/or clinopyroxene, hornblende, mica, and oxides as well as later alteration products. Anorthositic rocks of mappable extent have not been found.

No isotopic age determinations have so far been carried out on rocks west of the Ataneq fault, but it is likely that the amphibolites and associated rocks are equivalent to the Malene supracrustal rocks of the Godthåbsfjord region (McGregor, 1973; Bridgwater et al., 1976; Hall, 1980a).

\section{Dioritic rocks}

Further outcrops of the diorite complex recognised by R.P.H and D.J.H. in the northwestern part of the map sheet (Hall \& Hughes, 1982) were identified in 1982. These rocks frequently preserve primary discordant relations to the metamorphic banding and fabric in the amphibolitic rocks, and locally abundant, closely packed amphibolite xenoliths form an intrusion breccia agmatite within a diorite matrix. At least one tectono-metamorphic episode therefore separates the formation of the volcanics and gabbros from the intrusion of the diorite complex. These diorites are net-veined and therefore clearly older than the quartzo-feldspathic gneisses which form the bulk of the rocks of this area. An isolated group of small (less than $1 \mathrm{~km}^{2}$ ) outcrops of younger diorite, which is discordant to the main gneisses of the area, was found by A.A.G. in the south-west corner of the map sheet. 


\section{Quartzo-feldspathic gneisses}

Multiphase tonalitic to granitic biotite (-hornblende) gneisses, both homogeneous and weakly migmatitic varieties, underlie most of the map sheet area and are probably equivalent to the Nûk gneisses in the Godthåbsfjord region. The gneisses are clearly younger than, and intrusive into the amphibolitic horizons that occur within them. Dark, often migmatitic hornblende-rich gneisses are the oldest phases and occur as sheets associated with amphibolite screens or as inclusions within the younger and more leucocratic gneisses.

The main gneiss phases have intruded the earlier rocks (amphibolites and ultramafic rocks, diorites and early dark gneisses) both as sheets and by magmatic stoping. Spectacular agmatites that are interpreted as primary intrusive structures are common both in the north-western and south-western parts of the map area. Locally, agmatitic gneisses which are formed of abundant, apparently granodioritic xenoliths/enclaves within a coarser (?) granitic matrix, resemble those found in both the Fiskenæsset region (Myers, 1978) and in East Greenland (Bridgwater et al., 1978). The gneisses are variable in composition and texture, but away from the amphibolite horizons they are frequently homogeneous, weakly foliated, medium-grained rocks with only few foreign inclusions.

\section{Taserssuaq tonalite}

About $900 \mathrm{~km}^{2}$ of the central part of the map sheet is occupied by a very homogeneous but multiphase grey, medium-grained, weakly foliated biotite- and hornblende-bearing quartzo-feldspathic rock, which is almost devoid of such basic and ultrabasic horizons that characterise the gneisses to its west and north (fig. 7). This body continues south of the map sheet boundary and has been named the 'Taserssuaq granodiorite' by Allaart et al. (1977). It appears to be younger than the surrounding homogeneous gneisses. A limited number of thin sections from east and north of Taserssuaq show that it is not a granodiorite, but a series of quartz diorites, tonalites and trondhjemites consisting of $10-40 \%$ quartz, $55-75 \%$ plagioclase, and 10-25\% biotite and hornblende, whereas K-feldspar is almost totally absent. We therefore propose that the name is changed to Taserssuaq tonalite. It abuts on the Ataneq fault to its east, whereas the nature of its contacts with the gneisses to the north and west are often difficult to establish in the field. In the area mapped by R.P.H. and D.J.H. in the north-west of the map sheet relations to the surrounding gneisses are tectonic and ambiguous (Hall \& Hughes, 1982), but locally both south and east of this area the Taserssuaq tonalite contains identifiable enclaves of more distinctly foliated gneiss up to a few hundred metres away from its margins. Near the southern map sheet boundary west of Taserssuaq and especially in the larger area between Sarqap sermia and the Ataneq fault Taserssuaq tonalite interfingers with and contains rafts of the neighbouring gneisses on a kilometre-scale. Sometimes contact relations in this tract are obscured by large amounts of granitic neosome that brecciates the margins of the Taserssuaq tonalite and the adjacent migmatites.

The central part of the Taserssuaq tonalite (north of Taserssuaq) is only known from the earlier reconnaissance work, whereas the Taserssuaq tonalite east of Taserssuaq was map-

Fig. 7. Simplified geological map of the Isukasia map sheet. The asterisk by Isukasia indicates the locality of the acid dyke investigated by Kalsbeek \& Taylor (this volume). 


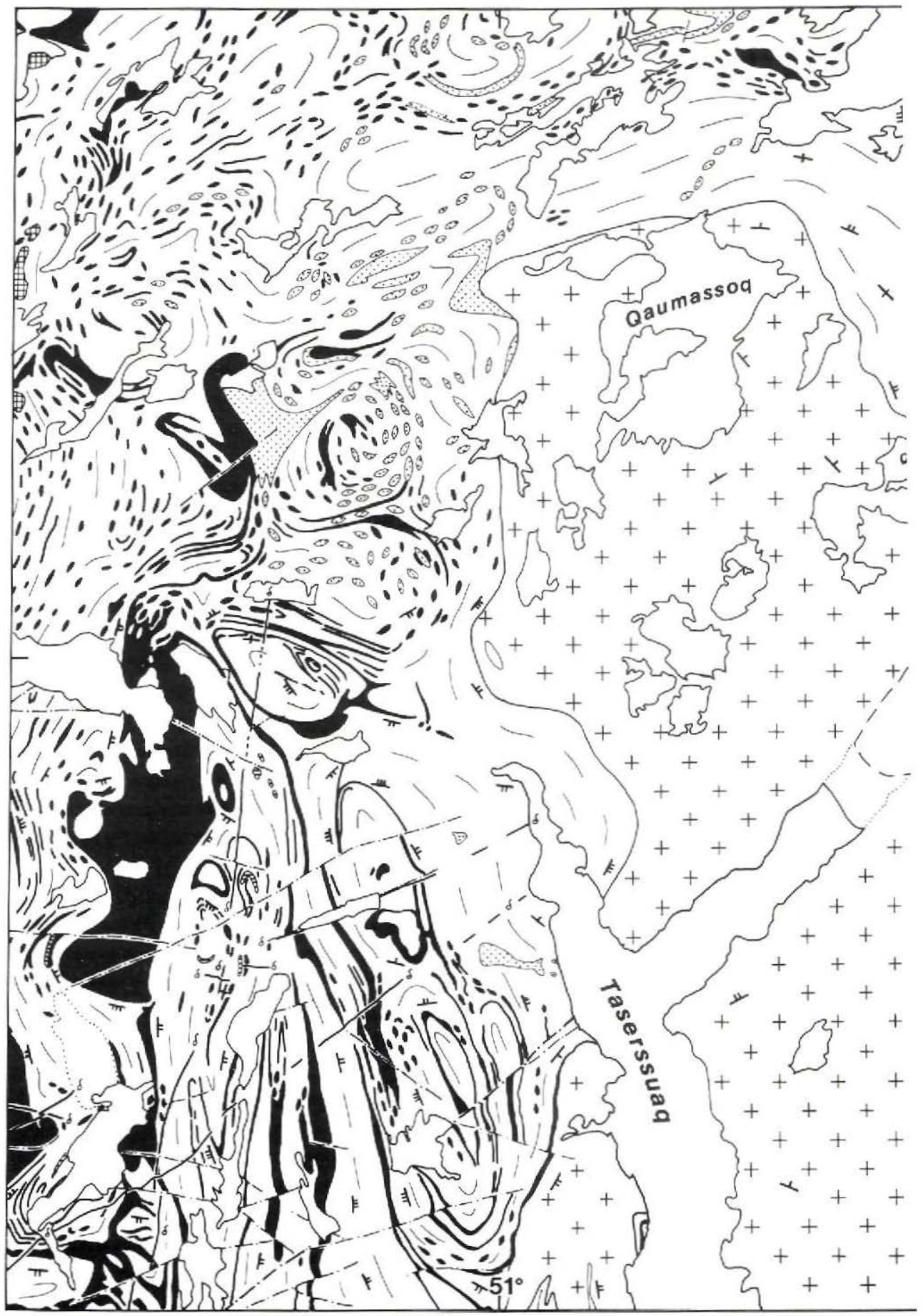

Fiskefjord 


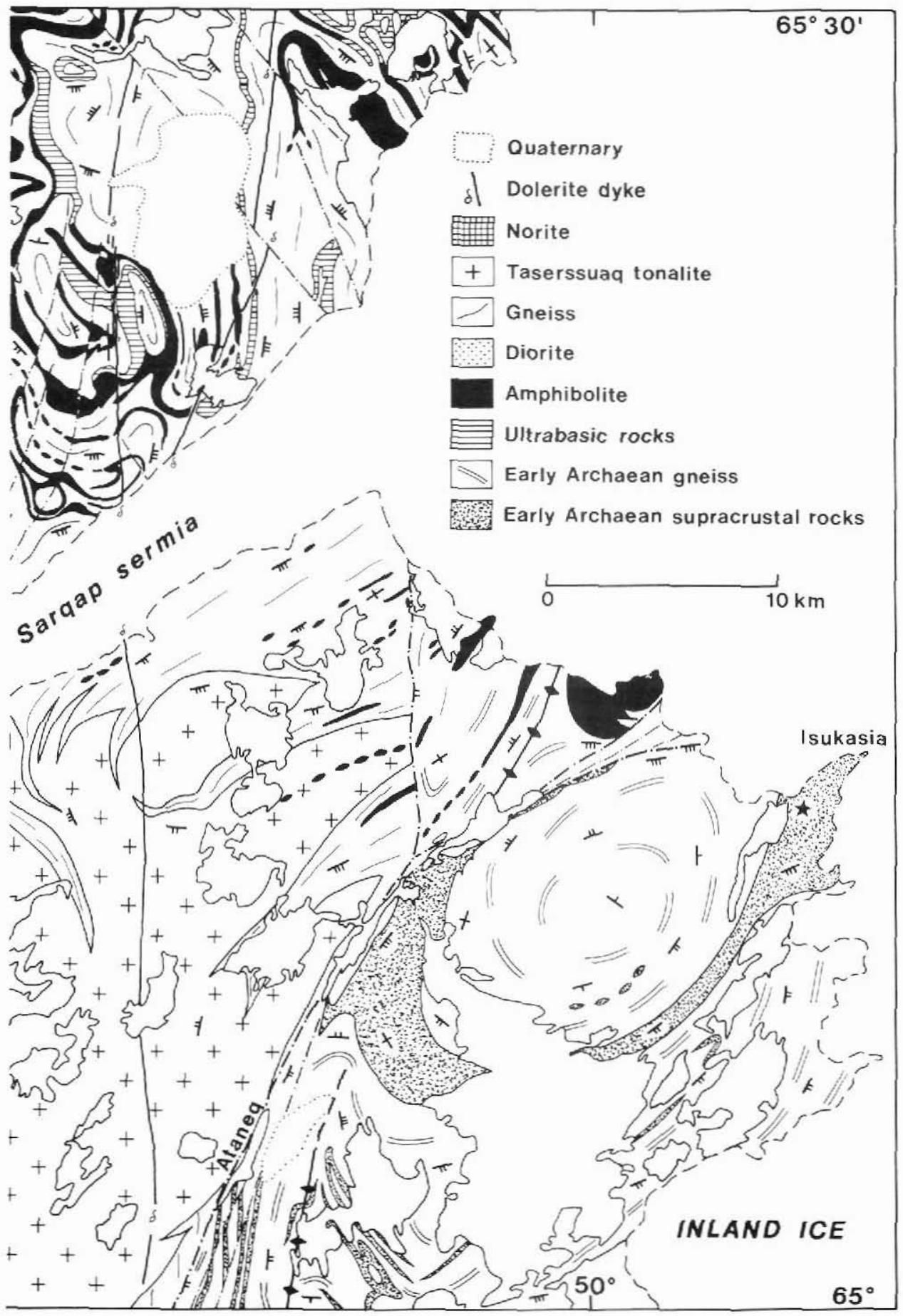


ped by A.P.N. in 1982. In the western part of this area it is predominantly composed of tonalitic medium-grained grey rocks virtually free of deformed pegmatite layering, but with a faint biotite-hornblende foliation and locally compositional layering on a scale of 1 to 200 $\mathrm{cm}$. Normally this layering is sharp, and thin layers of constant thickness have been followed for more than $100 \mathrm{~m}$. At a few localities layers that grade upwards from dark bases to pale tops were observed. Dips of weak foliation and compositional layering in this central part of the Taserssuaq tonalite are commonly under $30^{\circ}$ and only rarely exceed $60^{\circ}$, and define a synform with a north-west plunging axis (fig. 7). On approaching the Ataneq fault both the Taserssuaq tonalite and the migmatitic gneiss tracts that interfinger with it have steeply dipping foliations and compositional layering is almost absent. The tonalites that apparently form the bulk of the body are clearly multiphase, but it has not been possible to map out the distribution of individual members. Contrary to observations during the reconnaissance mapping (Allaart et al., 1978), the Taserssuaq tonalite contains insignificant amounts of inclusions. These include sparse inclusions of brecciated coarse-grained homogeneous metagabbro, and pegmatite-layered gneiss and amphibolite which commonly show a more complex history than the Taserssuaq tonalite. There are also synplutonic granitic to aplitic units, and fine-grained grey dioritic dykes less than $1 \mathrm{~m}$ wide, which are commonly disrupted into blebs.

\section{Grey dykes}

Fine-grained pale grey dykes presumably of tonalitic to granitic composition, normally only about a decimetre wide, are found sporadically in the gneisses. They are clearly discordant, but often almost parallel to gneiss foliations, and they often have cuspate margins. They can rarely be followed for more than a few tens of metres. In some areas the grey dykes seem to have been intruded into hot country rocks towards the end of the latest main phase of deformation; in the north-western part of the map sheet they are frequently associated with still younger east-north-east trending shear zones and commonly carry epidote.

\section{Norites}

A suite of bodies of basic material occurs at the western boundary of the area between $65^{\circ} 15^{\prime}$ and $65^{\circ} 30^{\prime} \mathrm{N}$. These have been identified as norites during previous work by geologists of Kryolitselskabet Øresund A/S and the GGU helicopter reconnaissance mapping in 1977 (Allaart et al., 1978). They are typically comprised of a massive, medium-grained equigranular assemblage of plagioclase-hornblende-clinopyroxene-orthopyroxene, but a hornblende-plagioclase variety commonly occurs towards the margins of the bodies. Because of this mineralogy, the weathered field appearance of the rocks is very similar to that of the granulite facies diorites of the area, and also to the granulite facies metagabbroic amphibolites. However, the norites locally contain abundant inclusions of both mixed amphibolite and gneiss fragments. This composite rock has the same agmatitic appearance as the 'ultrabasic pipe' which occurs on the large nunatak Majorqap alángua, to the east of Sukkertoppen (Hall, 1980b). Despite this evidence, problems arise in designating smaller, poorly exposed two-pyroxene-bearing basic bodies, in which neither inclusions nor veining occur. 


\section{Dolerite dykes}

The youngest rocks in the area are unmetamorphosed dolerite dykes, probably of early Proterozoic age, equivalent to MD dykes elsewhere in southern West Greenland. Two sets with trends of about $010^{\circ}$ and $100^{\circ}$ are dark grey, brownish grey weathering rocks composed of fine-grained plagioclase and clinopyroxene with ophitic textures. Both these sets are cut by a $60^{\circ}$ trending generation of almost black dykes with centimetre-sized, strongly zoned plagioclase xenocrysts.

\section{Faults}

The Isukasia map sheet area is cut by the Fiskefjord and Ataneq faults.

The Fiskefjord fault is vertical and has a general trend of $050^{\circ}$. At the head of Fiskefjord it has dextral displacement of about $2 \mathrm{~km}$ but this gradually diminishes towards the north-east, where the single fault line is replaced by a conjugate system of $070^{\circ}$ trending dextral, and $125^{\circ}$ trending sinistral faults indicating a general east-west compression. On approaching Taserssuaq, a single fault with the $050^{\circ}$ trend reappears with a lateral displacement of about $1 \mathrm{~km}$. It probably continues further north-east under Sarqap sermia. In the map sheet area the Fiskefjord fault is represented by a thin $10-30 \mathrm{~m}$ wide zone of crushed, often pink rocks. It does not greatly affect rocks outside this zone. It post-dates at least the north-south trending dykes.

The Ataneq fault separates early Archaean rocks in the easternmost part of the area from younger gneisses and the Taserssuaq tonalite to the west. The latest movements post-date all pegmatite veins, but no relations to the MD dykes have been established. From $65^{\circ} \mathrm{N}$ to the north-western side of the Isua supracrustal belt the main fault is $200 \mathrm{~m}$ wide with minor additional fractures on either side. It trends $c .020^{\circ}$ and dips $45^{\circ}$ to $60^{\circ}$ to the east. Then it branches to the north and north-east. Its most important northern branch reaches the Inland Ice just south of Sarqap sermia. The north-eastern branch, which lies within the early Archaean section, is less than $50 \mathrm{~m}$ wide with a south-easterly dip which passes into a splay system of steeply dipping fractures near to the Inland Ice.

There is a weak linear fabric in the fault, which records predominantly normal movement with a subordinate dextral component. Dextral displacements over minor associated faults are also observed.

\section{Deformation and metamorphism west of the Ataneq fault}

The continuous horizons of amphibolite and ultramafic rocks in the north-eastern and south-western parts of the area outline complex fold patterns on a horizontal scale of up to $10 \mathrm{~km}$. Elongate basin and dome structures with variable general trends are common, in which earlier tight to isoclinal folds occur comprising both the mafic rocks and the gneisses that have intruded them. Still on outcrop scale older fold structures in the banded amphibolites are often seen, which are truncated by the gneisses. The development of these large mappable structures was followed in the south-western part of the map sheet (area mapped by A.A.G.) by open folding with $070^{\circ}$ trending subhorizontal axes, which reorientated earlier small-scale structures but did not drastically modify the large-scale patterns. Also strong deformation along a straight vertical north-south belt occurred just east of the head 
of Fiskefjord. In the north-western part of the map sheet, the complete agmatisation and fragmentation of the supracrustal rocks during the intrusion of the precursors to the gneisses have made it impossible to follow many of the large structures. The amphibolite belts degenerate into inclusion trains and then vanish completely both along and across strike as leucocratic material starts to predominate. Both here and in the other parts of the map sheet area the gneisses are generally only very weakly foliated except close to the horizons of amphibolite and ultramafic rocks.

A.P.N. established two phases of deformation within the Taserssuaq tonalite east of Taserssuaq. The occurrence of folded gneiss and amphibolite enclaves in the Taserssuaq tonalite and its locally discordant margins suggest that it has undergone a simpler structural history than the surrounding gneisses.

The largest part of the map area consists of amphibolite facies rocks. Only minor areas to the south-west and west are underlain by dark, granular gneisses and weakly foliated mafic rocks with granulite facies parageneses containing orthopyroxene and plagioclase. Away from these areas there is a gradual, apparently retrogressive transition into amphibolite facies rocks. Normally basic and intermediate rocks seem to preserve hypersthene better during retrogression than adjacent, more leucocratic material, but in some cases it is not clear whether the latest, most leucocratic gneisses were injected after the granulite facies metamorphism. However, a characteristic recrystallisation texture, so-called 'blebby texture' (P. R. A. Wells; D. Bridgwater and V. R. McGregor, personal communication, 1974 and 1978), in which small secondary biotite and hornblende grains are concentrated in centimetre-sized spots or blebs, sometimes with cores of fine-grained green amphibole, is found in gneisses adjacent to granulite facies areas. This suggests that the rocks in question have been retrogressed under static conditions from granulite facies. Blebby textures have also been observed sporadically within the Taserssuaq tonalite east of Taserssuaq, and at present it is not known how much of the area has undergone granulite facies metamorphism.

While the granulite facies metamorphism and subsequent retrogression generally appear to post-date deformation, the straight belt deformation east of Fiskefjord mentioned above has caused retrogression, bleaching and partial remobilisation of granulite facies gneisses.

The gneisses were evidently intruded in several pulses, but it is not known at present whether their intrusion, deformation and metamorphism took place as a single large event or as mutually discrete episodes. While the earliest gneisses, now found as horizons associated with the amphibolites, may have been injected as sheets, there is evidence that some of the later gneisses were intruded as diapiric bodies that rose into the cores of already existing or developing large-scale folds in the more basic rocks, modified their structure, and heavily agmatised their margins.

The genetic relations between the Taserssuaq tonalite and the homogeneous gneisses around it also remain to be solved. The best criteria for distinguishing them are the general absence of mafic amphibolitic horizons and gneissic structures within the Taserssuaq tonalite. Contact relations are often not clear, and the apparently simple structural history of the Taserssuaq tonalite may be a result of its homogeneity. No geochemical data exist as yet to establish whether there is any compositional and genetic difference between the Taserssuaq tonalite and the surrounding gneisses. 


\section{References}

Allaart, J. H., Friend, C. R. L., Hall, R. P., Jensen, S. B. \& Roberts, I. W. N. 1978: Continued 1:500000 reconnaissance mapping in the Precambrian of the Sukkertoppen region, southern West Greenland. Rapp. Grønlands geol. Unders. 90, 50-54.

Allaart, J. H., Hall, R. P., Jensen, S. B. \& Stecher, O. 1982: Mapping in the Isukasia area. Rapp. Grønlands geol. Unders. 110, 44-45.

Allaart, J. H., Jensen, S. B., McGregor, V. R. \& Walton, B. J. 1977: Reconnaissance mapping for the 1:500000 map sheet in the Godthåb-Isua region, southern West Greenland, Rapp. Grønlands geol. Unders. 85, 50-54.

Bridgwater, D., Davies, F. B., Gill, R. C. O., Gorman, B. E., Myers, J. S., Pedersen, S. \& Taylor, P. 1978: Precambrian and Tertiary geology between Kangerdlugssuaq and Angmagssalik, East Greenland. Rapp. Grønlands geol. Unders. 83, 17 pp.

Bridgwater, D., Keto, L., McGregor, V. R. \& Myers, J. S. 1976: Archaean gneiss complex of Greenland. In Escher, A. \& Watt, W. S. (edit.) Geology of Greenland, 18-75. Copenhagen: Geol. Surv. Greenland.

Hall, R. P. 1980a: The tholeiitic and komatiitic affinities of the Malene metavolcanic amphibolites from Ivisârtoq, southern West Greenland. Rapp. Gronlands geol. Unders. 97, 20 pp.

Hall, R. P. 1980b: An ultrabasic pipe in the eastern Sukkertoppen region, southern West Greenland. Rapp. Gronlands geol. Unders. 100, 69-73.

Hall, R. P. \& Hughes, D. J. 1982: Transitional amphibolite-granulite facies granites, diorites and metavolcanic amphibolites in the Isukasia map sheet, southern West Greenland. Rapp. Grønlands geol. Unders. 110, 46-49.

McGregor, V. R. 1973: The early Precambrian gneisses of the Godthåb district, West Greenland. Phil. Trans. R. Soc. Lond. A 273, 343-358.

McGregor, V. R. \& Mason, B. 1977: Petrogenesis and geochemistry of metabasaltic and metasedimentary enclaves in the 3700 m.y. Amittsoq gneisses of the Godthåb region, West Greenland. Amer. Miner. 62, 887-904.

Myers, J. S. 1978: Formation of banded gneisses by deformation of igneous rocks. Precambrian Res. 6 , 43-64.

Nutman, A. P. 1982: Further work on the early Archaean rocks of the Isukasia area, southern West Greenland. Rapp. Grønlands geol. Unders. 110, 49-54.

Nutman, A. P., Bridgwater, D., Dimroth, E., Gill, R. \& Rosing, M. in press: Field work on the early (3700 Ma) Archaean rocks of the Isua supracrustal belt and adjacent gneisses. Rapp. Grønlands geol. Unders. 112.

D.J.H. \& R.P.H., Department of Geology,

Portsmouth Polytechnic,

Burnaby Road,

Portsmouth PO1 $3 Q L$,

U.K.
o.S., Departement de Geologie, Université de Montreal, Montreal, Quebec HC3 3J7, Canada. 